\author{
G. KOWALEWSKA, M. LOTOCKA
}

\title{
COPPER COMPLE XESWITH THE PORPHYRIN RING OF CHLOROPHYLL IN PHYTOPLANKTON CELLS
}

\author{
Institute of Oceanology, \\ Sopot, Poland
}

\begin{abstract}
Natural plankton samples were collected within June - November 1988 in the Southern Baltic. Species composition was determined and chlorophyll extracts from the samples were analyzed for chlorophyll and copper content. The $\mathrm{Cu}$ content in extracts from those samples dominated by phytoplankton was considerable, especially during bloom ( $\mathrm{Cu} / \mathrm{Mg}$ ratio of up to 0.1 ), in contrast to samples with zooplankton predominance (zero $\mathrm{Cu} / \mathrm{Mg}$ ratio). The data confirm results of previous studies on the blue-green alga Anabaena variabilis, proving the formation of a copper-chlorophyll complex in algal cells cultured in a high $\mathrm{Cu}$ concentration medium. Effects of such factors as light, $\mathrm{pH}, \mathrm{Cu}$ and $\mathrm{Fe}$ concentrations in the medium on $\mathrm{Cu}$ incorporation were studied in batch cultures of the blue-green algae A. variabilis and Anacystis nidulans. The experiments showed replacement of $\mathrm{Mg}$ by $\mathrm{Cu}$ to occur in live algal cells, the process requiring light to occur. Moreover, certain $\mathrm{Cu}$ concentrations stimulate an increase in chlorophyll content of the blue-green algal cultures. Fixation of some molecules of chlorophyll by copper such that the cell has to produce new chlorophyll molecules in order to function normally cannot be excluded.
\end{abstract}

\section{INTRODUCTION}

Copper is an essential element for the normal growth and physiological activity of unicellular algae, but at higher concentrations it alters the basic cell functions (Kowalewska 1988a). The main physiological effects caused by high copper concentrations are: 1 - effects on growth rate (Morel and Morel-Laurens 1983), and 2 - effects on photosynthesis (Steemann Nielsen and Wium-Andersen 1971). That is why copper chemistry in the environment is connected with algal blooms, a phenomenon still intriguing to scientists. 
The method of cyanobacterial bloom inhibition by adding copper to lake water has been known since the beginning of this century. Concentrations used ranged most often within $20-1000 \mu \mathrm{g} / \mathrm{dm}^{3}$ (Gachter et al. 1973).

All the toxic effects of copper on unicellular algae depend to a considerable extent on chemical speciation of the element. It is generally accepted that only ionic copper is toxic for algae. It is hence difficult to determine a concentration level above which copper affects normal functions of algal cells, as it forms various associations with different inorganic and organic ligands occurring in the environment (Kowalewska 1988b).

Those effects depend also on an organism exposed, because various species differ considerably in their resistance to toxic effects of copper on growth and photosynthesis. Predominantly, green algae are less sensitive, their growth being even stimulated at low $\mathrm{Cu}$ concentrations, while blue-greens are the most sensitive algae (Sueur et al. 1982). Sensitivity of diatoms and dinoflagellates varies greatly from species to species. Some authors contend that variation in resistance to copper induces the so-called "succession of species" (Granéli et al. 1986; Morel and Morel-Laurens 1983).

Earlier work carried out on the blue-green alga Anabaena variabilis (Kowalewska et al. 1987; Kowalewska and Hoffmann 1989) has indicated that copper replaces magnesium in the chlorophyll porphyrin ring at high $\mathrm{Cu}$ concentrations. This hypothesis was put forward in the literature many years ago, but was not supported by any experimental evidence (Azeez and Baner jee 1987; Gross et al. 1970; Wu and Lorentzen 1984).

In the present work, marine plankton was studied with respect to a possibility of copper-chlorophyll complex formation in cells. Besides, effects of such factors as light, pif, $\mathrm{Cu}$ and $\mathrm{Fe}$ concentrations in the medium on copper incorporation were studied on laboratory-grown cultures of blue-green algae.

\section{MATERIALS AND METHODS}

Location of sampling stations

Location of sampling stations is presented in Fig. 1. Plankton samples were collected within June - November 1988 in the Southern Baltic. An aliquot of each sample was formalin-preserved for species identification, the remainder being frozen until further analysis in the laboratory.

\section{Laboratory cultures of algae}

The studies concerned two blue-green species: Anabaena variabilis and Anacystis nidulans, both originating form the Institute of Oceanology collection. The algae were cultured in $50 \mathrm{~cm}^{3}$ of Bold's basal medium, BBM (Bischoff and Bold 1963) in $100 \mathrm{~cm}^{3}$ 
Sampling stations

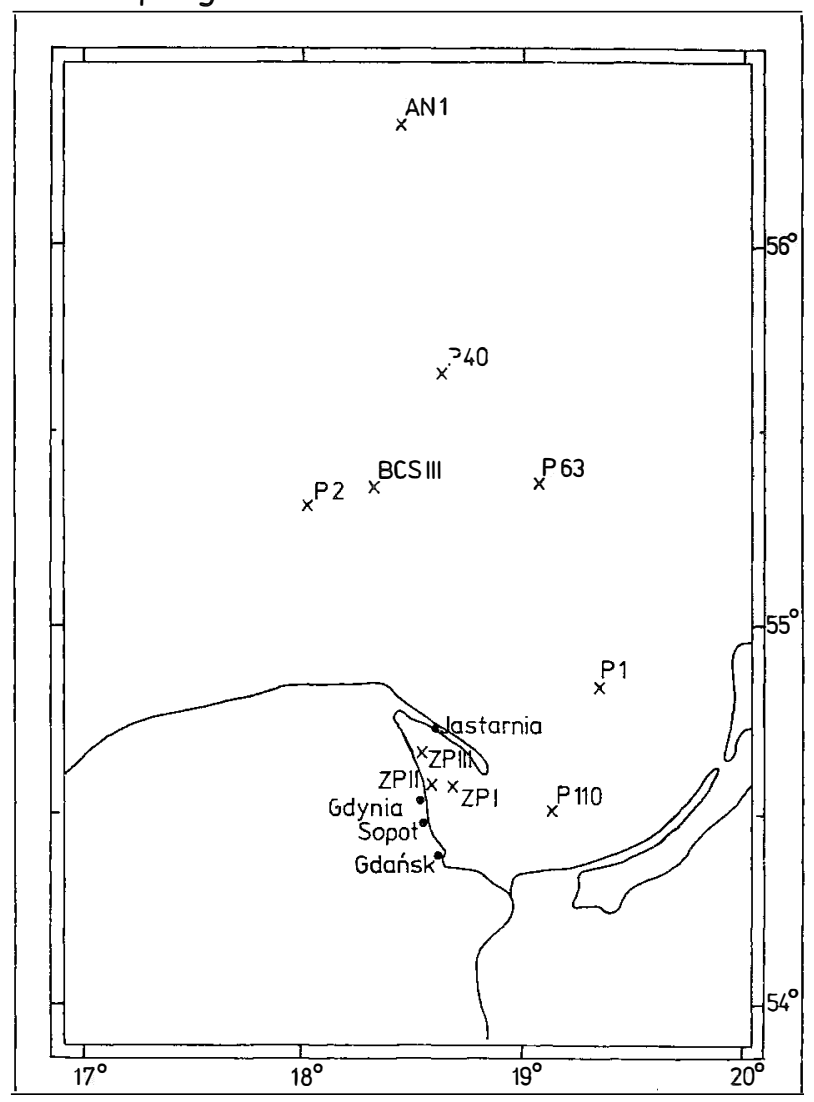

Fig. 1. Location of sampling stations in the Baltic Sea in 1988

total volume conical flasks at constant illumination $\left(5 \mu \mathrm{E} / \mathrm{m}^{2} \mathrm{~s}\right)$ at $25^{\circ} \mathrm{C}$ for one week. Subsequently, in the case of Anabaena variabilis whose cells settled on the bottom of the flask, the medium was decanted and $100 \mathrm{~cm}^{3}$ of fresh BBM (prepared with or without iron) were added to the culture. In the case of Anacystis nidulans, a $5 \mathrm{~cm}^{3}$ aliquot was transferred to a conical flask containing $10 \mathrm{~cm}^{3}$ of fresh BBM prepared with or without iron. Then, in both cases, i.e. Anabaena variabilis and Anacystis nidulans cultures, $5 \mathrm{~cm}^{3}$ aliquots were collected for an initial chlorophyll content assay. The remainder of each sample was divided into two portions and the stock solution of $\mathrm{CuSO}_{4}$ was added to the two samples; $\mathrm{pH}$ of the sterilized $\mathrm{BBM}$ with $\mathrm{CuSO}_{4}$ added at a concentration of the order of $1 \mathrm{mg} / \mathrm{dm}^{3}$ was 5 ; $\mathrm{pH} 8$ was obtained by adding a $\mathrm{KOH}$ solution. Such a double set of cultures was prepared twice, i.e. each analysis at the same experimental conditions was run four times. 
Determination of copper and chlorophyll content

An algal sample was filtered through a glass-fibre Whatman GF/C filter. The filter was washed with redistilled water and extracted with $10 \mathrm{~cm}^{3}$ acetone, following which the sample was centrifuged and the supernatant decanted. The filter was washed with acetone $\left(2 \mathrm{~cm}^{3}\right)$ and centrifuged again. The combined acetone fractions were transferred to a separation funnel with hexane $\left(2 \mathrm{~cm}^{3}\right)$ and redistilled water $\left(2 \mathrm{~cm}^{3}\right)$ was added. After mixing, chlorophyll and its derivatives were in the hexane layer.

Chlorophyll was determined by magnesium assays, as each molecule of the compound contains a single $\mathrm{Mg}$ ion; $2 \mathrm{~cm}^{3}$ of the hexane layer were heated in a quartz beaker and, after evaporation of the solvent, the sample was mineralized with $3 \mathrm{~cm}^{3}$ $\mathrm{HNO}_{3}(3.5 \mathrm{~N})$. The residue was dissolved in $3 \mathrm{~cm}^{3}$ of redistilled water. Magnesium and copper were determined in flame atomic absorption spectroscope (Instrumental Laboratory, Type 151). Sensitivity of the method was $0.05 \mu \mathrm{g} \mathrm{Cu} / \mathrm{cm}^{3}$ and $0.001 \mu \mathrm{g}$ $\mathrm{Mg} / \mathrm{cm}^{3}$, i.e. about $0.0003 \mu$ Mole chlorophyll.

\section{RESULTS AND DISCUSSION}

Tables 1 and 2 summarize the results of copper and magnesium assays in the plankton samples collected from the Baltic Sea. Table 3 presents the species composition. In the samples containing mainly phytoplankton, the copper content is noticeable,

Table 1

Copper and magnesium contents in the plankton samples dominated by phytoplankton, collected in the Baltic Sea in 1988

\begin{tabular}{|c|c|c|c|c|c|c|}
\hline No. & Station & $\begin{array}{l}\text { Month of } \\
\text { collection }\end{array}$ & $\mathrm{Cu}(\mu \mathrm{g})$ & $\mathrm{Mg}(\mu \mathrm{g})$ & \multicolumn{2}{|c|}{$\begin{array}{c}\mathrm{Cu} / \mathrm{Mg} \\
\mu \mathrm{Mole} / \mu \mathrm{Mole}\end{array}$} \\
\hline 1 & $\mathrm{BCS} 3 \mathrm{X}$ & June & 0.204 & 1.234 & 0.062 & \\
\hline 2 & P 110 & June & 0.068 & 5.949 & 0.004 & \\
\hline \multirow[t]{3}{*}{3} & ZP I & July & 0.090 & 0.710 & 0.047 & \\
\hline & & & 0.085 & 0.910 & 0.034 & 0.05 \\
\hline & & & 0.090 & 0.548 & 0.061 & \pm 0.013 \\
\hline 4 & ZP I & September & 0.201 & 3.808 & 0.020 & \\
\hline 5 & ZP II & September & 0.105 & 2.389 & 0.016 & \\
\hline 6 & ZP II & October & 0.651 & 4.196 & 0.058 & \\
\hline \multirow[t]{2}{*}{7} & ZP I & November & 0.237 & 0.999 & 0.089 & 0.10 \\
\hline & & & 0.335 & 1.248 & 0.101 & \pm 0.010 \\
\hline
\end{tabular}


Table 2

Copper and magnesium contents in the plankton samples dominated by zooplankton, collected in the Baltic Sea in 1988

\begin{tabular}{|c|l|l|l|l|l|}
\hline No & Station & $\begin{array}{c}\text { Month of } \\
\text { collection }\end{array}$ & $\mathrm{Cu}(\mu \mathrm{g})$ & $\mathrm{Mg}(\mu \mathrm{g})$ & $\begin{array}{c}\mathrm{Cu} / \mathrm{Mg} \\
\mu \mathrm{Mole} / \mu \mathrm{Mole}\end{array}$ \\
\hline 1 & AN 1 & June & 0 & 0.367 & 0 \\
2 & P 40 & June & 0 & 0.301 & - \\
3 & P 1 & June & 0 & 0.030 & 0 \\
4 & P 63 & June & 0 & 0.320 & 0 \\
5 & BCS3X & June & 0 & 0.130 & 0 \\
6 & P 2 & June & & & \\
\hline
\end{tabular}

Samples of the plankton dominated by phytoplankton, collected in 1988: species composition

\begin{tabular}{|c|c|c|c|c|c|}
\hline No & Station & $\begin{array}{l}\text { Month of } \\
\text { collection }\end{array}$ & $\begin{array}{l}\text { Main } \\
\text { classes }\end{array}$ & $\%$ & Dominant species \\
\hline 1 & $\mathrm{BCS} 3 \mathrm{X}$ & June & Cyanophyta & 99.8 & $\begin{array}{c}\text { Aphanizomenon } \\
\text { flos-aquae }\end{array}$ \\
\hline 2 & P 110 & June & Cyanophyta & 99.9 & $\begin{array}{c}\text { Aphanizomenon } \\
\text { flos-aquae }\end{array}$ \\
\hline 3 & ZP I & July & Cyanophyta & 90.0 & $\begin{array}{l}\text { Aphanizomenon } \\
\text { flos-aquae } \\
\text { Nodularia } \\
\text { spumigena }\end{array}$ \\
\hline 4 & ZP I & September & $\begin{array}{c}\text { Chlorophyto } \\
\text { Bacillario- } \\
\text { phyceae }\end{array}$ & $\begin{array}{l}47.8 \\
37.2\end{array}$ & $\begin{array}{l}\text { Cladophora sp. } \\
\text { Coscinodiscus } \\
\text { grani }\end{array}$ \\
\hline 5 & ZP II & September & $\begin{array}{l}\text { Chlorophyto } \\
\text { Bacillario- }\end{array}$ & 83.4 & Cladophora sp. \\
\hline 6 & ZP II & October & phyceae & 90.6 & $\begin{array}{l}\text { Coscinodiscus } \\
\text { grani }\end{array}$ \\
\hline 7 & ZP I & November & $\begin{array}{l}\text { Bacillario- } \\
\text { phyceae }\end{array}$ & 99.4 & $\begin{array}{l}\text { Coscinodiscus } \\
\text { groni }\end{array}$ \\
\hline
\end{tabular}

especially in those samples collected during a bloom (e.g. ZP 1 November). In such cases, the $\mathrm{Cu} / \mathrm{Mg}$ ratio reached even 0.1 . In the light of the previous results (Kowalewska et al. 1987; Kowalewska and Hoffmann 1989) we may suppose that the cause lies 
Anabaena variabilis

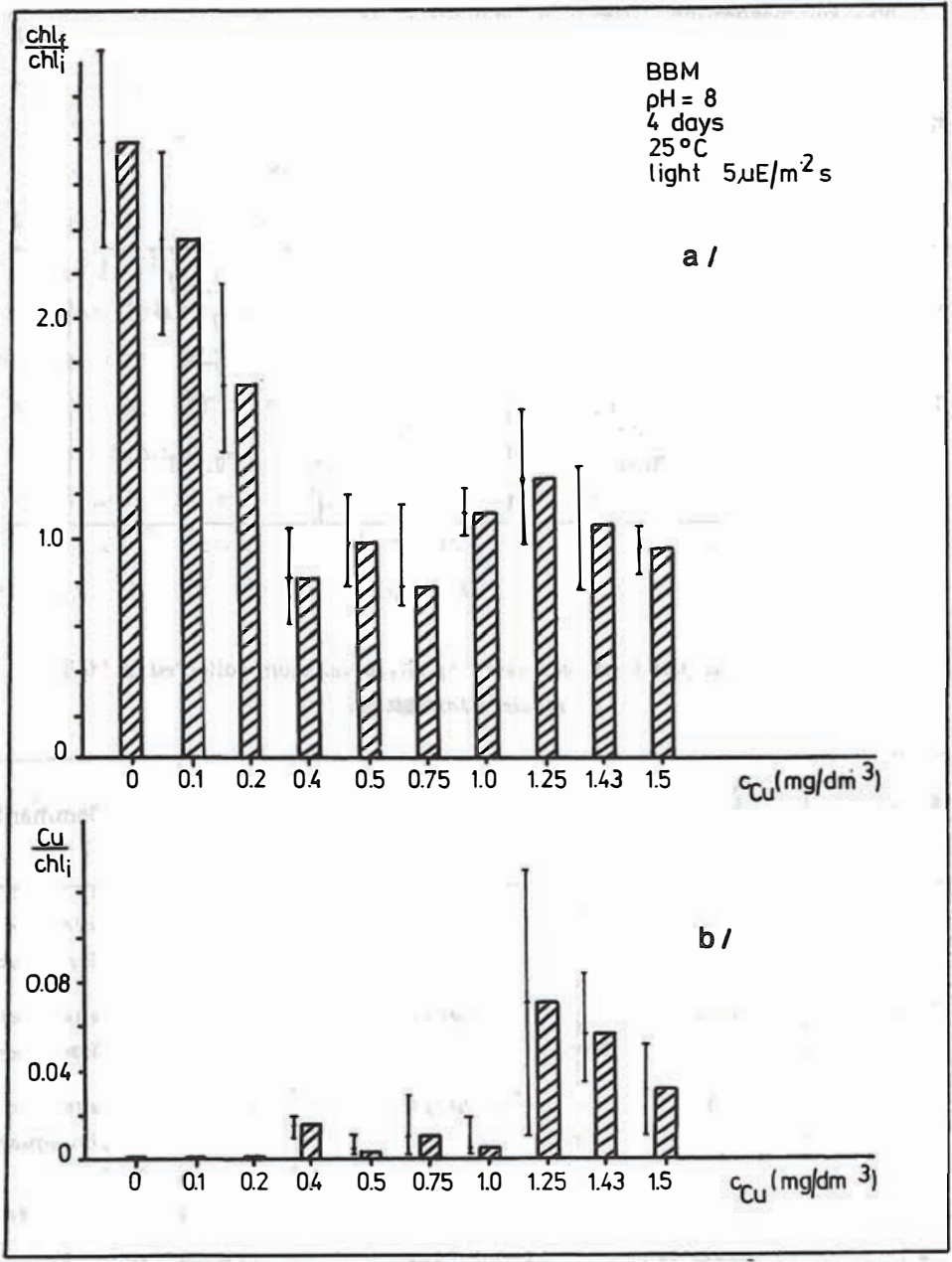

Fig. 2. Anabaena variabilis batch cultures in $\mathrm{BBM}$, at $\mathrm{pH}=8,25^{\circ} \mathrm{C}$, exposed to light of $5 \mu \mathrm{E} / \mathrm{m}^{2} \mathrm{s:}$ a) chlorophyll to initial chlorophyll ratio $\left(\mathrm{chl}_{\mathrm{f}} / \mathrm{chl}_{\mathrm{j}}\right)$ vs copper concentration in medium $\left(\mathrm{C}_{\mathrm{Cu}}\right)$; b) copper to initial chlorophyll ratio $\left(\mathrm{Cu} / \mathrm{chl}_{\mathrm{i}}\right)$ vs copper concentration in medium $\left(\mathrm{C}_{\mathrm{Cu}}\right)$

in the copper-chlorophyll complex formation. The samples containing mainly zocplankton showed no copper or the contents were negligible, which confirms the above suggestion. The observed $\mathrm{Cu} / \mathrm{Mg}$ ratios equal to, for instance, 0.1 means that in one out of 10 chlorophyll molecules the $\mathrm{Mg}$ ion was replaced by $\mathrm{Cu}$. The above results are the first data concerning the natural plankton whereby the presence of copper in the chlorophyll extract was found. The subsequent part of the work deals with the question whether copper was incorporated in live algal cells and, if so, under what conditions the substitution could occur. 


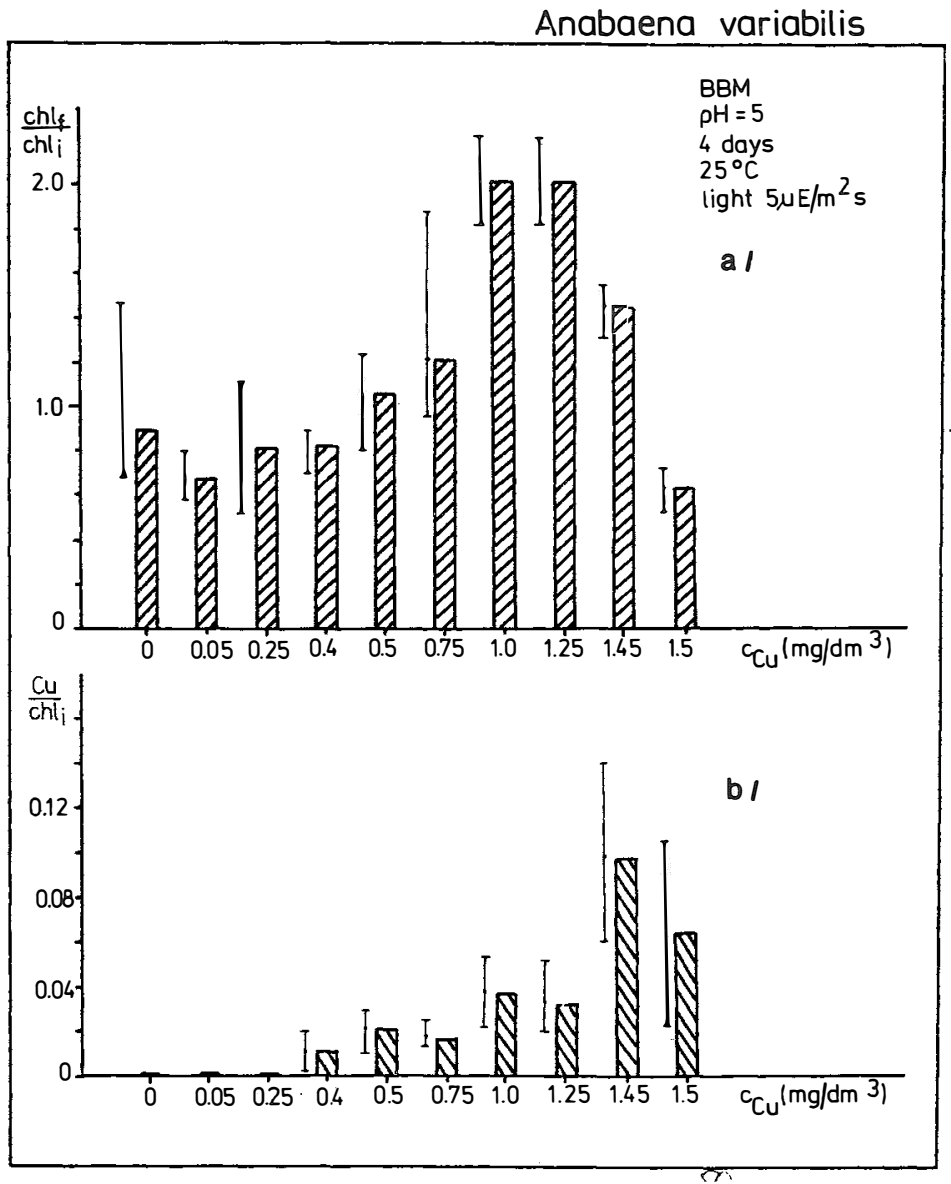

Fig. 3. Anabaena varlabilis batch cultures in $\mathrm{BBM}$, at $\mathrm{pH}=15,25^{\circ} \mathrm{C}$, exposed to light of $5 \mu \mathrm{E} / \mathrm{m}^{2} \mathrm{s:}$ a) chlorophyll to initial chlorophyll ratio $\left(\mathrm{chl}_{\mathrm{f}} / \mathrm{chl}_{\mathrm{i}}\right)$ vs copper concentration in medium $\left(\mathrm{C}_{\mathrm{Cu}}\right)$; b) copper to initial chlorophyll ratio $\left(\mathrm{Cu} / \mathrm{chl}_{\mathrm{i}}\right)$ vs coppei concentration in medium $\left(\mathrm{C}_{\mathrm{Cu}}\right)$

Figs 2-7 present results of the studies on effects of $\mathrm{pH}$, light, $\mathrm{Cu}$ and $\mathrm{Fe}$ contents in the medium on the copper content in the blue-green algae chlorophyll extract. Figs 2-5 show results obtained for Anabaena variabilis, while Figs 6 and 7 illustrate the data for Anacystic nidulans.

Based on the above results, one observes firstly that both in the case of Anabaena variabilis and Anacystis nidulans, no copper was found in the chlorophyll extracts of cultures kept in darkness (Figs. $5 \mathrm{~b}$ and $7 \mathrm{~b}$ ). The observation confirms the literature data pointing to the fact that toxic effects of copper occur only in illumination (Azeez et al. 1987; Steemann Nielsen and Wium-Andersen 1971).

For both Anabaena variabilis and Anacystis nidulans, all the light-exposed cultures showed a decrease, and then again an increase to the maximum, in the chloro- 


\section{Anabaena variabilis}

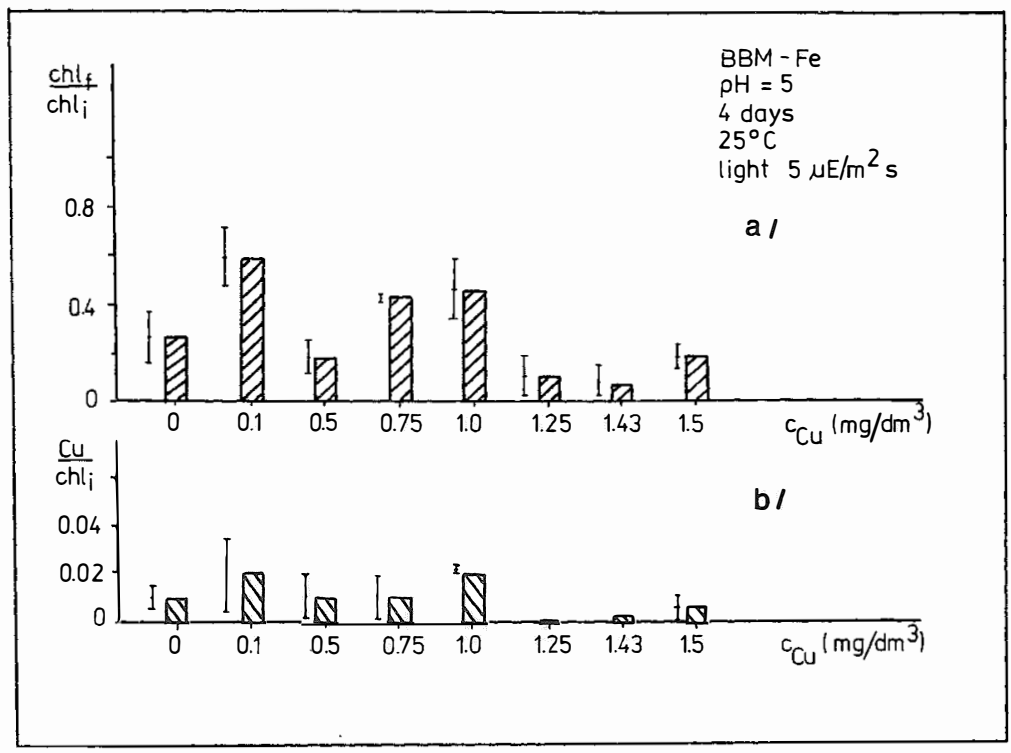

Fig. 4. Anabaena variabilis batch cultures in $\mathrm{BBM}-\mathrm{Fe}$, at $\mathrm{pH}=5,25^{\circ} \mathrm{C}$, exposed to light of $5 \mu \mathrm{E} / \mathrm{m}^{2} \mathrm{~s}$ : a) chlorophylll to initial chlorophyll ratio $\left(\mathrm{chl}_{\mathrm{f}} / \mathrm{chl}_{\mathrm{i}}\right)$ vs copper concentration in medium; b) copper to initial chlorophyll ratio $\left(\mathrm{Cu} / \mathrm{chl}_{\mathrm{i}}\right)$ vs copper concentration in medium $\left(\mathrm{C}_{\mathrm{Cu}}\right)$

Anabaena variabilis

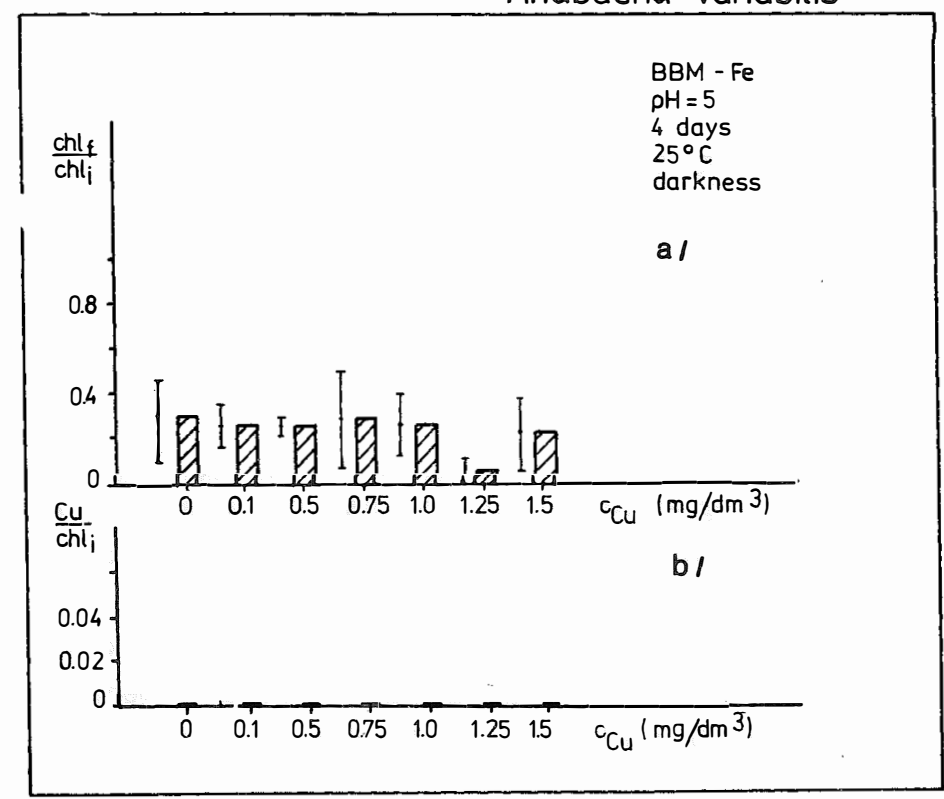

Fig. 5. Anabaena variabilis batch cultures in $\mathrm{BBM}-\mathrm{Fe}$, at $\mathrm{pH}=5,25^{\circ} \mathrm{C}$, darkness: a) chlorophyll to initial chlorophyll ratio $\left(\mathrm{chl}_{\mathrm{f}} / \mathrm{chl}_{\mathrm{i}}\right)$ vs copper concentration in medium $\left.\left(\mathrm{C}_{\mathrm{Cu}}\right) ; \mathrm{b}\right)$ copper to initial chlorophyll ratio $\left(\mathrm{Cu} / \mathrm{chl}_{\mathrm{j}}\right)$ vs copper concentration in medium $\left(\mathrm{C}_{\mathrm{Cu}}\right)$ 
Anacystis nidulans

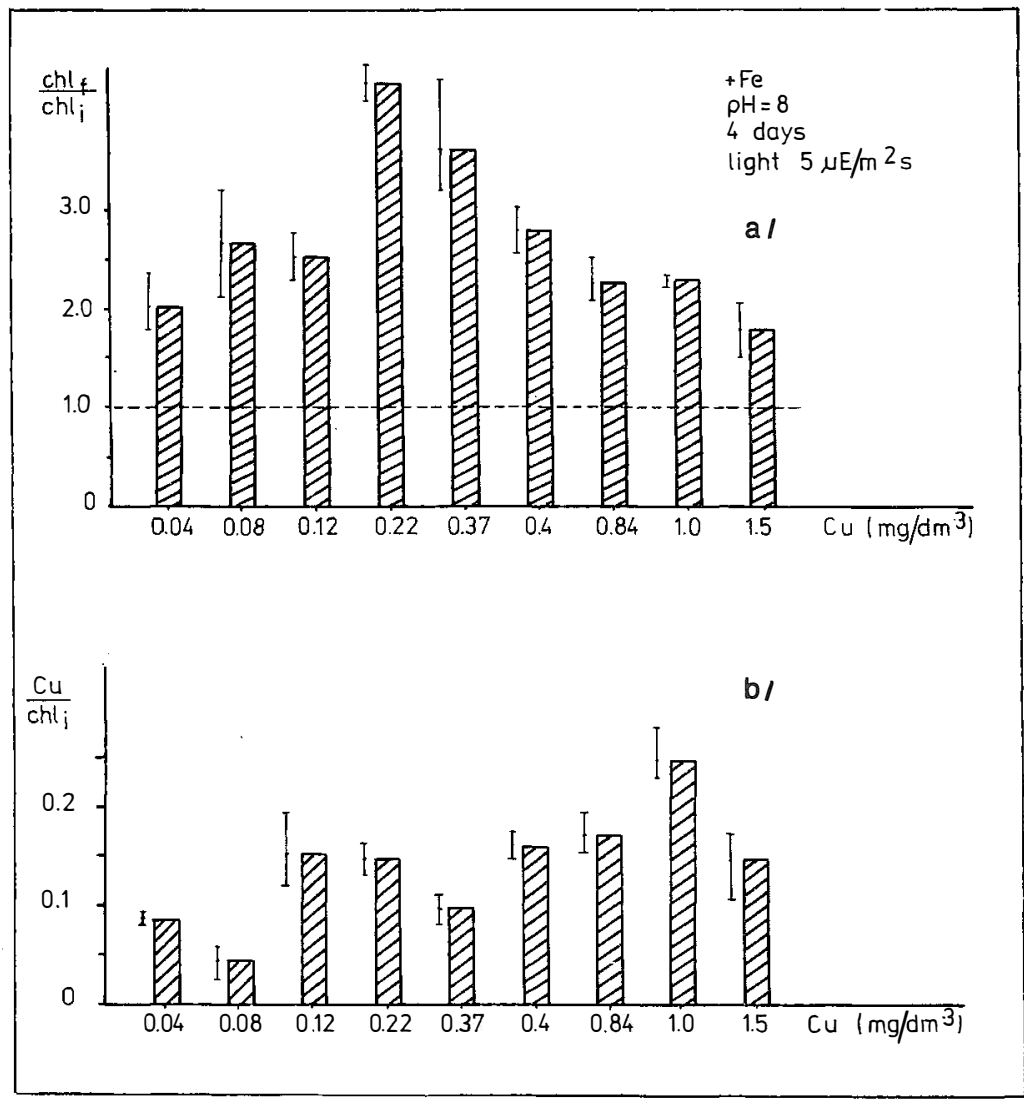

Fig. 6. Anacystis nidulans batch cultures in BBM, at $\mathrm{pH}=8,25^{\circ} \mathrm{C}$, exposed to light of $5 \mu \mathrm{E} / \mathrm{m}^{\circ} \mathrm{s}$ : a) chlorophyll ${ }^{-}$ to initial chlorophyll ratio $\left(\mathrm{chl}_{\mathfrak{f}} / \mathrm{chl}_{\mathfrak{j}}\right)$ vs copper concentration in medium $\left.\left(\mathrm{C}_{\mathrm{Cu}_{u}}\right) ; \mathrm{b}\right)$ copper to initial chlorophyll ratio $\left(\mathrm{Cu} / \mathrm{chl}_{\mathrm{i}}\right)$ vs copper concentration in medium $\left(\mathrm{C}_{\mathrm{Cu}}\right)$

phyll content to the initial chlorophyll content ratio $\left(\mathrm{chl}_{\mathrm{f}} / \mathrm{chl}_{\mathrm{i}}\right)$ in relation to copper concentrations in the medium $\left(\mathrm{C}_{\mathrm{Cu}}\right)$ (Figs 2a, 3a, 4a, 6a), but the function shifted along the abscissa depending on the presence in the medium of components affecting copper speciation. $\mathrm{pH}$ and $\mathrm{Fe}$ concentration are the major parameters which can change the equilibrium.

Two $\mathrm{pH}$ values were tested: $\mathrm{pH} 5$ at which copper should occur in solution mainly in the form of $\mathrm{Cu}^{2+}$ when considering the inorganic species only; and $\mathrm{pH} 8$ typical of the surface seawater, when the equilibrium is shifted towards the inorganic complexes $\mathrm{Cu}(\mathrm{OH})_{2}$ and $\mathrm{CuCO}_{3}$, that is when the amount of free $\mathrm{Cu}^{2+}$ ions is proportionally lower. Comparison of the results for Anabaena variabilis at $\mathrm{pH} 5$ and 8 (Figs 2a and $3 \mathrm{a}$ ) shows that the copper concentrations at which the $\mathrm{chl}_{\mathrm{f}} / \mathrm{chl}_{\mathrm{i}}$ vs. $\mathrm{C}_{\mathrm{Cu}}$ function 


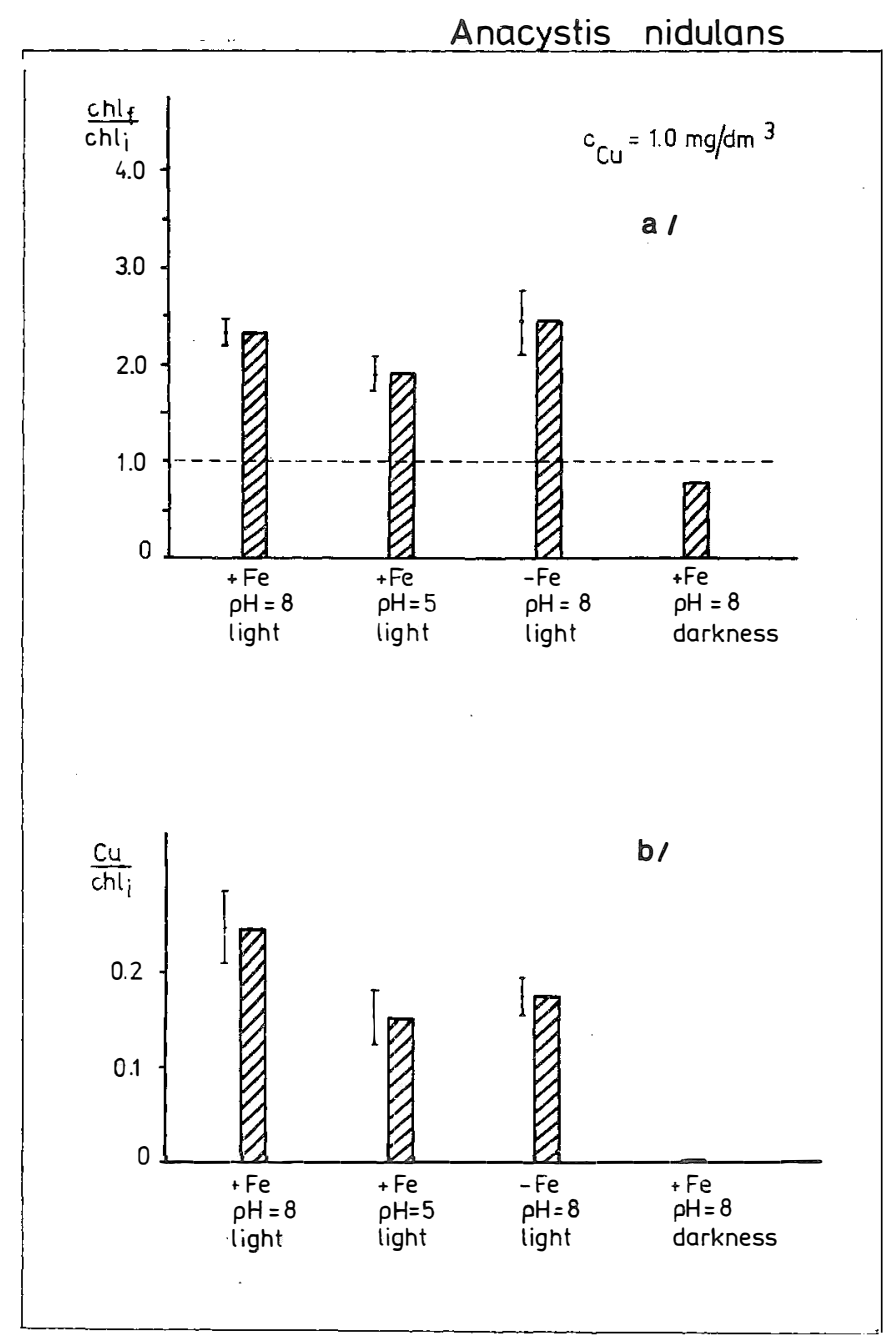

Fig. 7. Anacystis nidulans batch cultures in BBM with or without iron, copper concentrations in medium $\mathrm{C}_{\mathrm{Cu}}=1.0 \mathrm{mg} / \mathrm{dm}^{3}$, exposed to light of $5 \mu \mathrm{E} / \mathrm{m}^{2} \mathrm{~s}$ or kept in darkness: a) chlorophyll to initial chlorophyll ratio $\left.\left(\mathrm{chl}_{\mathrm{f}} / \mathrm{chl}_{\mathrm{j}}\right), \mathrm{b}\right)$ copper to initial chlorophyll ratio $\left(\mathrm{Cu} / \mathrm{chl}_{\mathrm{i}}\right)$

attains its maxima are $1.0-1.25 \mathrm{~g} / \mathrm{dm}^{3}$ and $1.25 \mathrm{mg} / \mathrm{dm}^{3}$, respectively, which is in agreement with the opinion mentioned at the beginning of ionic copper being more toxic to algae. The results obtained for Anabaena variabilis cultures kept in the medium with (Fig. 3a) and without (Fig. 4a) iron as well as those of Anacystis nidulans (Figs 6a and 7a) led to a similar conclusion, i.e. that copper is less toxic in the presence of iron, as the cultures were able to withstand much higher copper concentrations. 
Based on the results presented, we may judge Anabaena variabilis-to be more re sistant to copper than Anacystis nidulans because the $\mathrm{chl}_{\mathrm{f}} / \mathrm{chl}_{\mathrm{i}} \quad \mathrm{vs} \mathrm{C}_{\mathrm{Cu}}$ function reaches its maximum in the latter case at much lower $\mathrm{Cu}$ concentrations (cf Figs $2 \mathrm{a}$ and $6 a$ ), i.e. $1.25 \mathrm{mg} / \mathrm{dm}^{3}$ and $0.22 \mathrm{mg} / \mathrm{dm}^{3}$, respectively.

Along with the maximum of the $\mathrm{chl}_{\mathrm{f}} / \mathrm{chl}_{\mathrm{i}}$ vs. $\mathrm{C}_{\mathrm{Cu}}$ function, an increase in the copper content in the chlorophyll extract can be observed (Figs 2b, 3b, 4b, 6b). With reference to the previous studies on Anabaena variabilis (Kowalewska and Hoffmann 1989) which demonstrated the formation of the copper-chlorophyll complex in a high $\mathrm{Cu}$ concentration medium we may suppose that the copper found in the chlorophyll extract is fixed in such a complex. This conclusion, when applied to the present results, implies that within a certain copper concentration range, some chlorophyll molecules are complexed with copper and new molecules of chlorophyll have to be produced within the cells of the plant organisms studied to enable them to develop normally. Moreover, the results presented suggest that copper is incorporated in the chlorophyll porphyrin ring in live cells.

\section{CONCLUSIONS}

- The copper content in chlorophyll extracts from plankton samples dominated by phytoplankton, collected in the Baltic Sea, was substantial $(\mathrm{Cu} / \mathrm{Mg}$ ratios of up to 0.1 ) in contrast to samples dominated by zooplankton in which the ratio was null; it means that copper forms a complex with chlorophyll in phytoplankton cells.

- The experiments on laboratory cultures of two blue-green algal species, Anabaena variabilis and Anacystis nidulans, showed that the replacement of magnesium by copper occurs in live cells and that the process requires light to occur.

- Within a certain concentration range, copper stimulates the increase in chlorophyll content in blue-green algal cultures, which is possibly caused by copper fixing some chlorophyll molecules so that the cell has to produce new molecules of chlorophyll to function normally.

\section{ACKNOWLEDGEMENTS}

This work was carried out under the Project CPBP 03.10. The authors would like to thank Ms Ewa Legeżyńska, M.Sc. of the Institute of Oceanology, Polish Academy of Sciences in Sopot and Dr. Maria Szymelfenig of the Gdansk University for collecting the plankton samples. 


\section{REFERENCES}

Azeez P.Z.o D.K. Banerjee, 1987: Influence of light on chlorophyll a content of blue-green algae treated with heavy metals. Bull. Environm. Contam. Toxicol., 38: 1062-1069.

Bischoff $H_{0}, \mathbb{D}_{\text {. Bold, }}$ 1963: Physiological studies IV. In: George, E.A. (ed.): Culture Centre of Algae and Protozoa. List of Strains 1976. Institute of Terrestrial Ecology. Natural Environment Research Council.

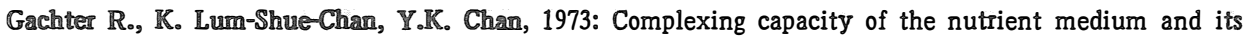
relation to inhibition of algal photosynthesis by copper. Schweiz. Z. Hydrol., 35: 252-261.

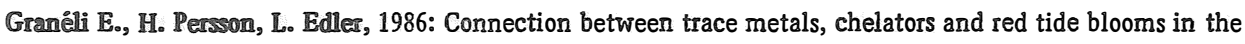
Laholm Bay - SE Kattegat. An experimental approach. Mar. Environm. Res., 18: 61-78.

Gross R.E., P. Pugno, W.M. Dugger, 1970: Observations of the mechanism of copper damage in Chlorella. Plant Physiol., 46: 183-185.

Kowalewska G., 1988a: Wpływ miedzi na fitoplankton w šrodowisku morskim. Wiad. Bot., 32: 9-20.

Kowalewsksa G., 1988b: Specjacja miedzi w wodzie morskiej. Wiad. Chem., 42: 295-307.

Kowalewaka G., L. Falkowski, S.K. Hofirnann, L. Szczepaniak, 1987: Replacement of magnesium by copper (II) in the chlorophyll porphyrin ring of planktonic algae. Acta Phys. Plant., 9: 43-52.

Kowalewsika G., S.K. Hiofimann, 1989: Identification of the copper porphyrin complex formed in cultures of blue-green alga Anabaena variabilis. Acta Phys. Plant., 11: 39-50.

Morel F.M.M., N.M.L. Morel-Laurens, 1983: Trace metals and plankton in the oceans: Facts and speculations. In: Wong C.S. et al. (eds): Trace metals in seawater. Plenum Press New York: 841-869.

Steernann Nielsen E., S. Wium-Andersen, 1971: The influence of copper on photosynthesis and growth in diatoms. Physiol. Plant., 24: 480-484.

Sueur S., C.M.G. van den Berg, J.P. Riley, 1982: Measurements of the metal complexing ability of exudates of marine macroalgae. Limnol. Oceanogr., 27: 536-543.

Wu J.T., H. Lorentzen, 1984: Effects of copper on photosynthesis in synchronous Chlorella cells. Bot. Bull. Acad. Sinica, 25: 125-132.

Authors' address:

Institute of Oceanology

Polish Academy of Sciences

ul. Powstańców Warszawy 55

Sopot

Poland 